Article

\title{
Spatio-Temporal Analysis of Intense Convective Storms Tracks in a Densely Urbanized Italian Basin
}

\author{
Matteo Sangiorgio ${ }^{1}(1)$ and Stefano Barindelli ${ }^{2, *}$ \\ 1 Department of Electronics, Information, and Bioengineering, Politecnico di Milano, 20133 Milan, Italy; \\ matteo.sangiorgio@polimi.it \\ 2 Department of Civil and Environmental Engineering, Politecnico di Milano, 20133 Milan, Italy \\ * Correspondence: stefano.barindelli@polimi.it
}

Received: 4 February 2020; Accepted: 22 March 2020; Published: 24 March 2020

\begin{abstract}
Intense convective storms usually produce large rainfall volumes in short time periods, increasing the risk of floods and causing damages to population, buildings, and infrastructures. In this paper, we propose a framework to couple visual and statistical analyses of convective thunderstorms at the basin scale, considering both the spatial and temporal dimensions of the process. The dataset analyzed in this paper contains intense convective events that occurred in seven years (2012-2018) in the Seveso-Olona-Lambro basin (North of Italy). The data has been acquired by MeteoSwiss using the Thunderstorm Radar Tracking (TRT) algorithm. The results show that the most favorable conditions for the formation of convective events occur in the early afternoon and during summertime, confirming the key role of the temperature in atmospheric convection. The orography emerged as a driver for convection, which takes place more frequently in mountain areas. The storm paths analysis shows that the predominant direction is from South-West to North-East. Considering storm duration, long-lasting events reach higher values of radar reflectivity and cover more extended areas than short-lasting ones. The results obtained can be exploited for many practical applications including nowcasting, alert systems, and sensors deployment.
\end{abstract}

Keywords: data exploration; convective thunderstorms; weather radar; spatio-temporal statistics

\section{Introduction}

Convective storms are a typical source of rainfall in many regions, especially during summer periods. The causes behind these phenomena are not completely known due to the complexity of the physical processes behind them, that jointly involves spatial and temporal aspects at different scales [1]. Several research studies tried to improve the understanding of convective storm mechanisms by collecting and analyzing observations of the past few decades. Radar-based climatology has been developed to clarify convective storm behaviors, distributions, and frequencies in different domains and environments [2-6].

Intense convective storms can cause adverse effect such as floods, landslides, hail, and strong winds. These extreme natural events, that will increase in frequency due to climate change $[7,8]$, cause not only huge economic damages, but also significant human losses. In the period 1994-2013, 6,863 natural disasters occurred worldwide, and more than $70 \%$ have been strictly related to severe rainfall events: 2,937 floods, and 1,942 storms. These phenomena affected 3 billion people, causing almost 310,000 deaths ( $30 \%$ of the human losses due to natural disasters), and more than 1,500 billion US\$ of economic damages $(60 \%$ of the total) [9].

It is thus fundamental to gain a better understanding of the physical processes behind convective storms. This is usually done by investigating the causes and the atmospheric mechanisms which originate these phenomena [10-12] and identifying the most critical areas by monitoring past 
events [13-15]. Among all the drivers that concur in the formation of such convective events, the temperature has a key role [16,17]. For this reason, global warming caused by climate change [18-24] could potentially strongly affect the behavior of such storms.

The convective storms usually interest limited areas, and their duration is almost always less than two hours [25]. Despite that, they often reach higher intensity in less time than orographic and frontal storms, originating fast but intense rainfalls, which are the worst case for the flood protection systems and other hydraulic infrastructures (e.g., sewer and subterranean urban streams) [26,27].

Researchers are trying to enhance the forecasting performances of convective rainfall events, integrating information extracted by the dataset available nowadays which couple traditional and innovative meteorological variables $[28,29]$. Other authors proposed to adopt a different paradigm, switching from the conventional physically-based meteorological model to more recent machine learning techniques [30-34] to exploit the huge amount of available data. A better understanding of the physical processes and the features characterizing convective events is important, to better define the equation of the physically based models on the one hand, and to properly select inputs and structure of the machine learning tools on the other.

The dataset considered in this paper has been acquired using the Thunderstorm Radar Tracking (TRT) algorithm developed by MeteoSwiss [35,36]. This algorithm couples traditional and innovative techniques and allows us to acquire the position of convective cells and follow their evolution through time. The result of the data acquisition process is a sequence of snapshots, one every five minutes, containing the convective cells characterized by a radar reflectivity exceeding a given threshold. Once acquired, the dataset can be used by the meteorologists to perform a visual analysis in order to examine the behavior of the convective cells and the relationships among different weather features [37]. Visualizing the sequence of snapshots is useful but working in this way the spatial and temporal dimensions of the process evolve at the same time. The main goal of our work consists of synthesizing general features of the behavior of the convective cells that occurred in the Lambro, Seveso, and Olona catchments in Northern Italy from 2012 to 2018. To do that, we performed statistical analyses splitting the spatial and the temporal aspects in order to focus on a single dimension. The spatial analysis allows us to visualize the high-risk areas, which could provide useful insights on how to deploy a meteorological monitoring network. It also allows us to obtain the climatology of the area of interest [38,39]. Conversely, the temporal dimension helps to visualize how the events are distributed within the month of the year, or within the hour of the day [24]. Coupling a visual and statistical exploration of the big data available can open an innovative perspective in the comprehension of meteorological aspects behind intense rain events [40].

The rest of this article is organized as follows. In Section 2, we briefly present some relevant features of the considered study area, and describe the convective thunderstorm events dataset. Section 3 reports the results of the statistical and graphical analysis performed, focusing on the spatial and temporal dimensions, and on the thunderstorm life cycle. In Section 4, we discuss the results obtained, and we draw some concluding remarks.

\section{Materials and Methods}

\subsection{Study Area}

The study area includes the hydrological basins of Seveso, Olona, and Lambro rivers and lies in the Northern part of Italy: latitude spans from $45.37 \mathrm{~N}$ to $45.93 \mathrm{~N}$, and longitude from $8.77 \mathrm{E}$ to $9.40 \mathrm{E}$, with an extension of approximately $1400 \mathrm{~km}^{2}$ (Figure 1). 

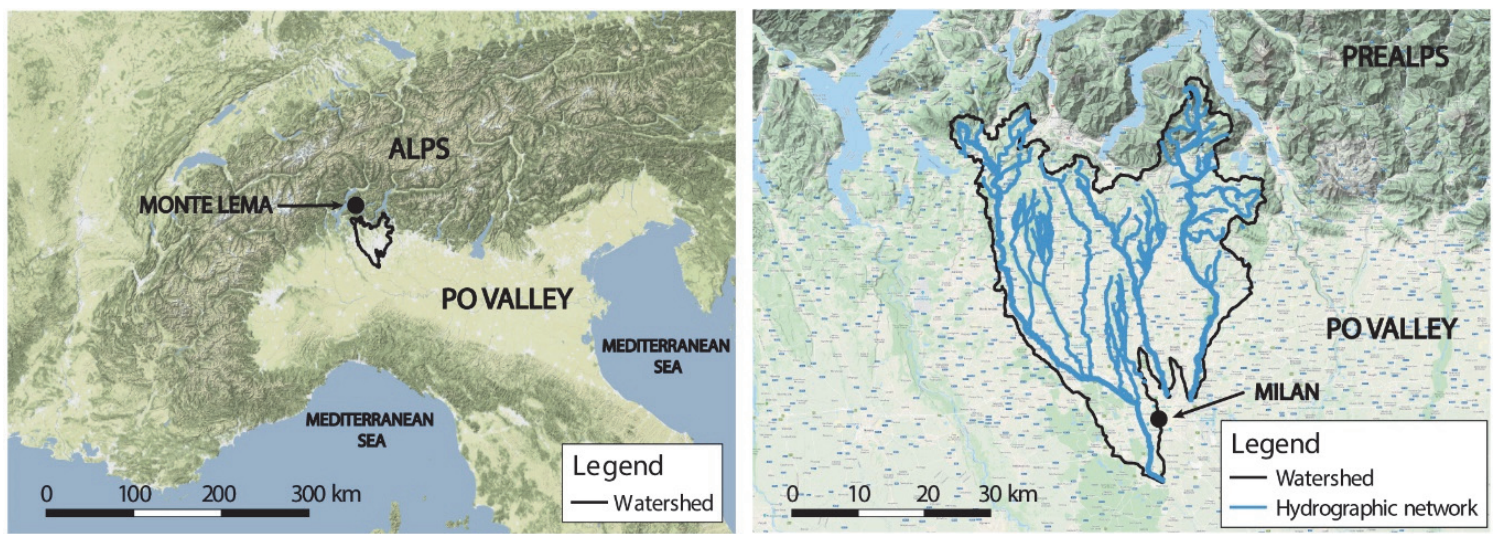

Figure 1. A geographical overview of the study area. The black line represents the watershed, and the light blue lines represent rivers and streams inside the area.

According to the Koppen classification [41], the study area is characterized by a temperate climate with typical patterns of the mid-latitude regions (Cfa in the Koppen notation). It is dominated by the presence of the Italian Prealps in the northern part, Milan municipality in the southern part, and an almost flat area in the middle with a strong connotation of urban sprawl. It is frequently affected by convective cells, especially during summer, due to its peculiar morphology. Quite often, humid air remains for long periods in the Po' Valley and is dragged by an uplift mechanism triggered by surface heating by the sun. The northern part of the considered area is windier (quite often during winter foehn rises) than the southern part, which is characterized by frequent foggy days and strong thermal inversions.

All these local drivers contribute to the vulnerability of the studied area from a hydrological perspective, and the need to understand deeply convective thunderstorms patterns, that quite often lead to high economic losses here.

\subsection{Convective Rain Dataset}

The convective rain dataset analyzed in this paper has been sampled with the MeteoSwiss TRT algorithm. This algorithm is fed with data recorded by the Swiss radar network. The closest radar to the region of study is located at Monte Lema (1626 m a.s.1.) in the Canton Ticino. Due to the orography of the area of interest and the radar position, there are no limitations in terms of coverage and blockage [42,43].

The dataset employed in this study spans the seven years from 2012 to 2018. The time resolution at which data were recorded was five minutes, while the spatial resolution was $2 \mathrm{~km}$. The algorithm was designed to identify convective cells, and it is based on an adaptive thresholding scheme which allows the detection of convective cells depending on their development phase [34]. Convective cells are considered intense and thus detected if they reach an area of $16 \mathrm{~km}^{2}$ at a minimum reflectivity of 36 $\mathrm{dBZ}$ and at least one pixel inside them attains $42 \mathrm{dBZ}$. These events are thus detected at a variable threshold, depending on their development phase. This allows the detection of thunderstorms at an early stage of their life cycles at the lowest possible reflectivity threshold, i.e. $36 \mathrm{dBZ}$, as well as in the mature phase at a higher threshold [34].

Adopting this technique, thunderstorms can be tracked very early during their growing phase as well as in the mature stage, and trajectories are created from a sequence of radar images [34]. For each convective cell and each time step, the dataset consists of a unique identification number, date and time of detection, coordinates of the center of gravity of the cell, velocity of the cell, area covered by the cell as a polygon feature, and mean and maximum reflectivity recorded.

Figure 2 shows an intuitive way to visualize the dataset. The whole sequence of snapshots, in principle, could be plotted one after the other with the desired temporal step. In this case, 10 minutes. This methodology could be useful to interpret convective events belonging to a particular temporal 
window visually, but it is not appropriate for long period analysis to understand systematic patterns during convection phases
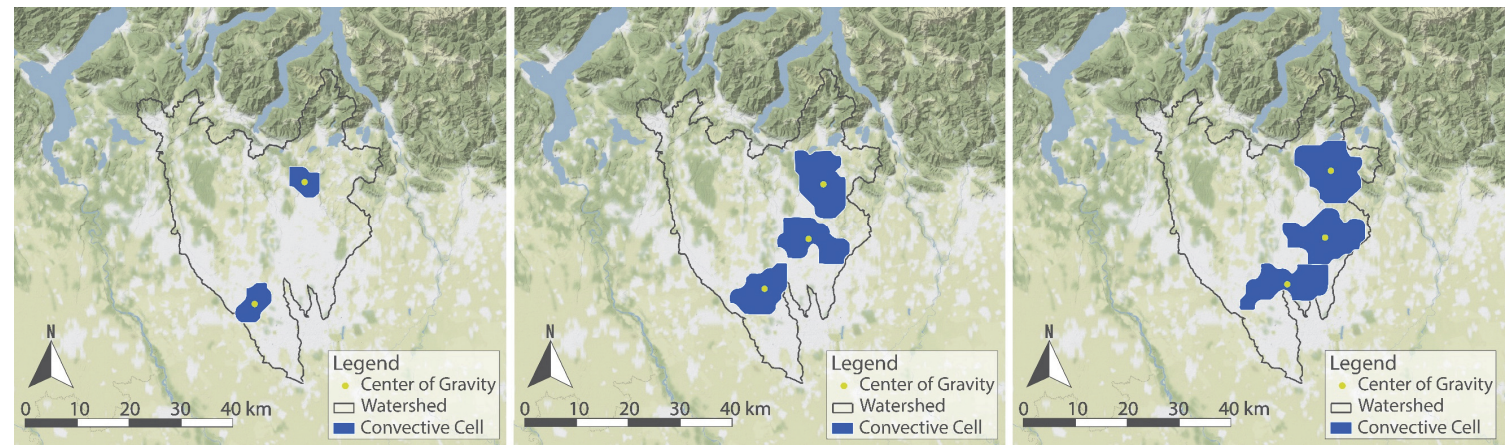

Figure 2. An example of visualization of three snapshots of convective storms event that occurred on 9 August 2018 (10:10 pm, left; 10:20 pm, center; 10:30 pm, right). The black line represents the watershed, the yellow dots are the centers of gravity, while the blue polygons represent convective cells.

A viable alternative consists in showing all the center of gravity trajectories on the same map (Figure 3). This procedure could be useful in visualizing a limited number of events, but it turns out to be inappropriate due to the high number of records stored in the dataset. The plot reported in Figure 3 does not help to synthesize any general features of the convective storms paths.

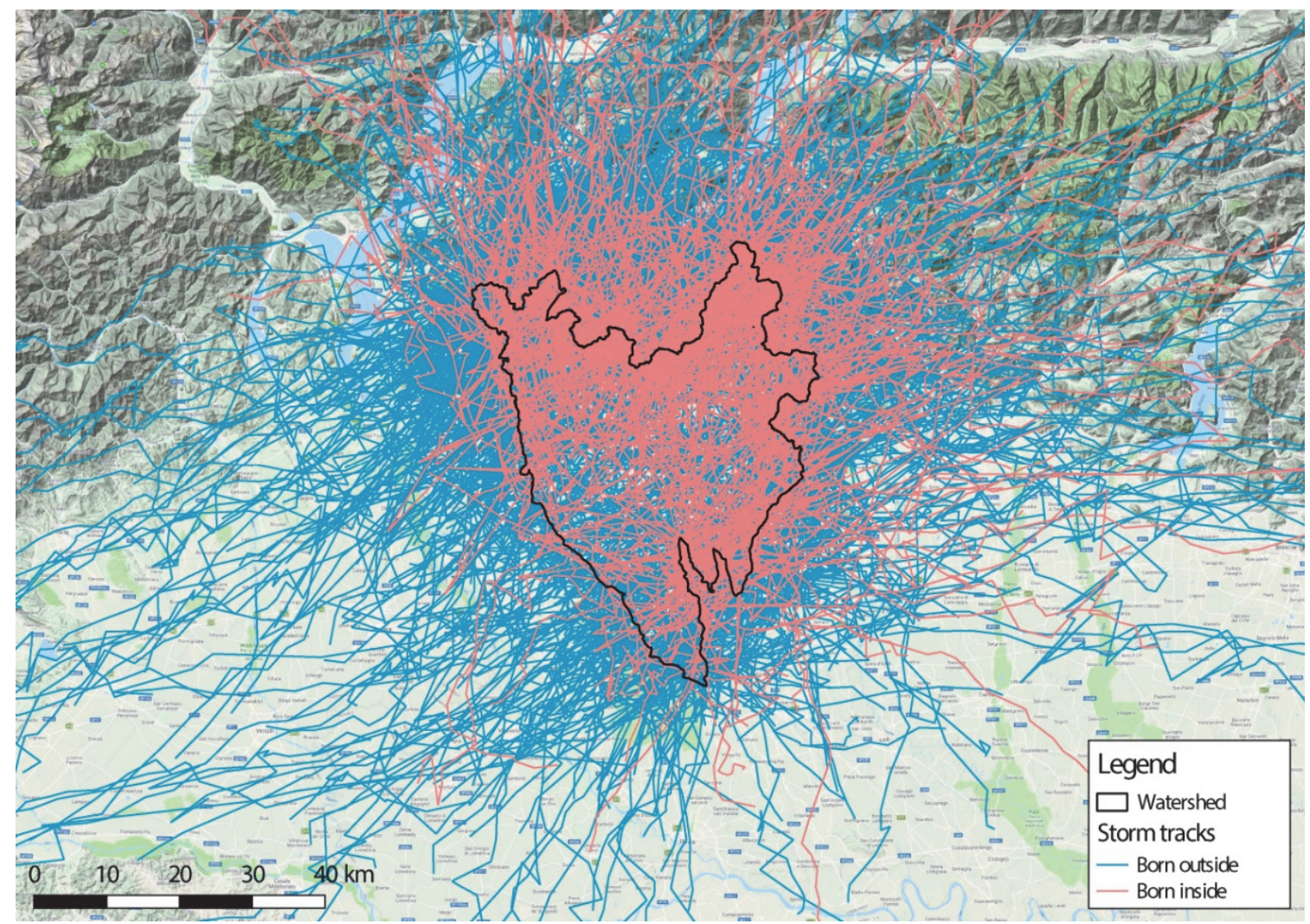

Figure 3. Convective events born inside (pink) and outside (light blue) the region of interest between 2012 and 2018. Subsequent centers of gravity's positions of the same event are linked with a straight line.

For this reason, a well-designed data visualization approach, able to highlight different aspects of the ongoing process, is the key to retrieving useful information hidden in the data. This task has been faced using Python libraries for data visualization (Matplotlib [44], Seaborn [45]) and for spatial 
analysis (GeoPandas [46], Geoplot [47], Cartopy [48], GDAL [49], Shapely [50]), together with QGIS software [51].

\section{Results}

The primary focus of this work was to visualize the key characteristics of the data and eliminate misleading interpretations. With this aim, the temporal and spatial scales were considered separately. In the following two subsections, a couple of different sets of figures are presented: the first deals with the spatial distribution of the data, and the second focuses on the temporal dimension of these phenomena. The last subsection provides an analysis of the storm's life cycle considering the duration of the events and how it is related to the reflectivity and the area of the convective thunderstorms.

\subsection{Spatial Focus}

The simplest attempt to deriving a spatial visualization consists of plotting the distribution of all the available centers of gravity inside the study area, producing a heatmap. Starting from this set of point features, a probability distribution adopting the standard Kernel Density Estimation (KDE) technique provided by Seaborn library was estimated (Figure 4).

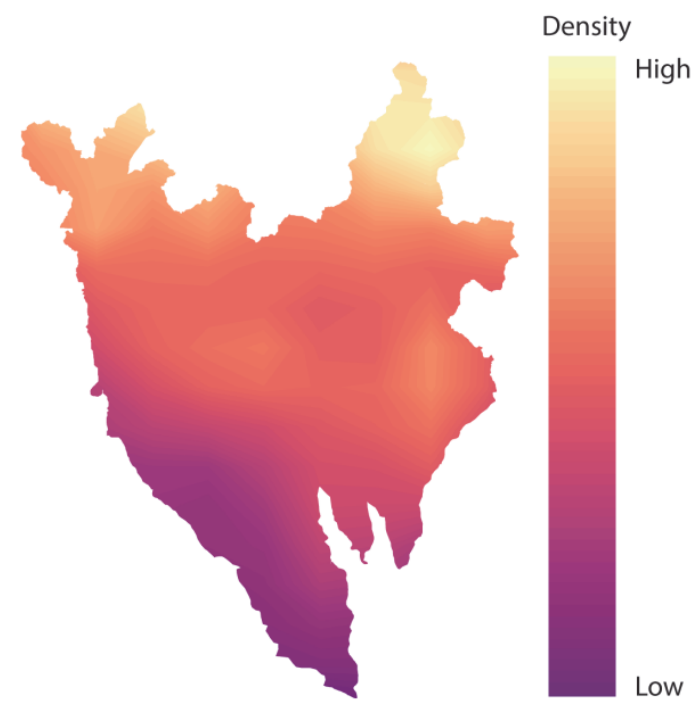

Figure 4. Distribution of all points. Light hue indicates high density, dark hue low density.

Figure 4 highlights the areas more frequently affected by the considered convective phenomena. As already underlined in previous research, the spatial distribution follows the orography of the basin [52]. The higher densities were observed in the North part of the basin, near the Prealps. The lower values in the South-West portion were probably due to dry winds coming from the Apennines mountains. The main drawback of this graph is that it mixes all the points, hiding behind the orographic effect some interesting patterns. Figure 4 could be very useful for the purpose of deploying a network of meteorological sensors. Locating them where the occurrence of intense rain events is more probable could give useful forecast insights.

Figure 4 reports a static representation of the dataset, not allowing us to figure out which are the most frequent paths followed by the convective cells. For this reason, an analysis of the average trajectories of the convective cells' centers of gravity was reported in Figure 5. On average, these trajectories were oriented from South-West to North-East due to local interaction of the air masses with orography and morphology of the region. This pattern has been extensively analyzed in [24] and it was confirmed by our analysis that the mid-tropospheric wind, coupled with the amount of moisture, is the main cause for this preferential direction, while local breeze system only affects probably the triggering areas. Due to the natural configuration of the region, South-West winds carry air masses 
rich in water vapor originating from the Mediterranean Sea, generating more favorable conditions for convection processes. Conversely, the presence of the Alps is a strong orographic obstacle to air mass flux coming from North-West directions. This is another reason why South-West winds are the main driver of convective thunderstorms.

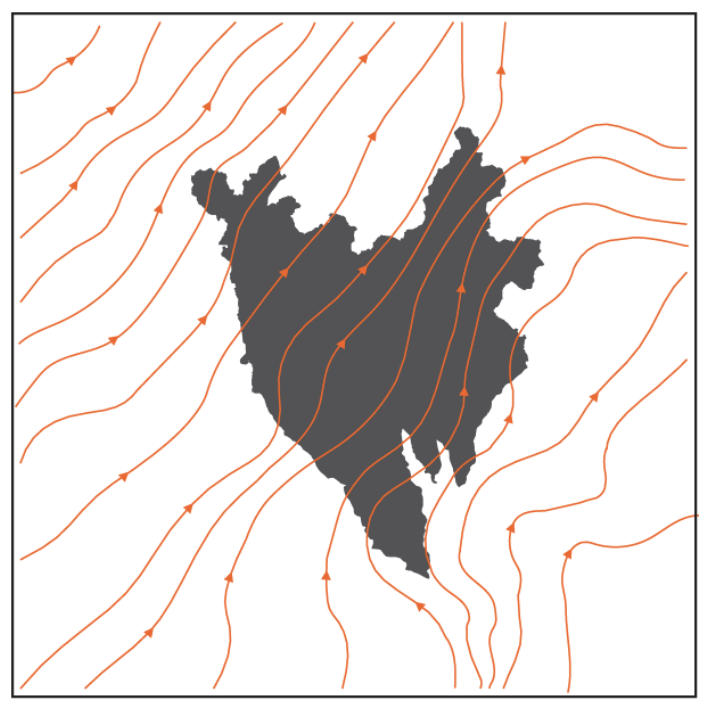

Figure 5. Representation of the average vector field of convective events born outside the basin.

\subsection{Temporal Focus}

While considering meteorological phenomena, it is also important to evaluate the temporal aspect of their dynamics. A visual analysis would help to spot some temporal structures, such as daily and annual periodicity, and possible increasing/decreasing trends. Figure 6 reports the annual distribution of convective events. The maximum number of convective cells (1119) was recorded during 2014, while values for the remaining years span from 600 to 900.

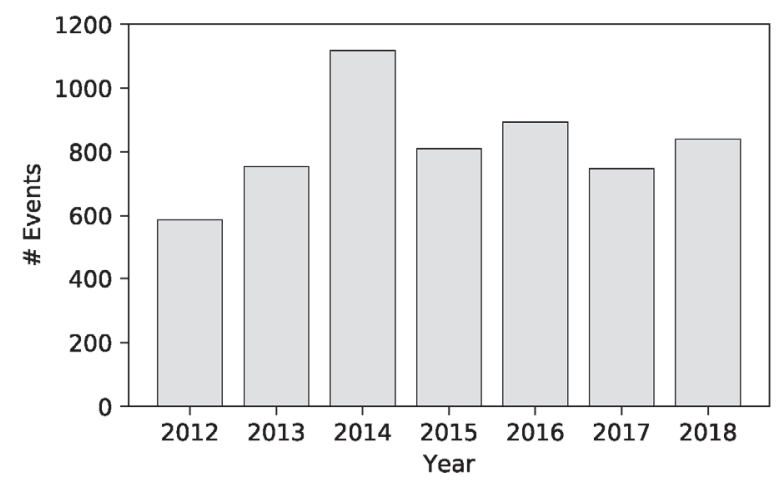

Figure 6. Distribution of the events per year.

As expected, the convective events also exhibit a seasonal periodicity (Figure 7). Convective events occur only during spring and summer (from April to September), suggesting that they are strongly related to high-temperature values. Of course, it is during these two seasons, especially summer, that solar radiation reaches its peak. The diurnal temperature during these months leads to a strong increase in surface temperature that affects the lower atmospheric layer by warming up atmospheric masses. This is a typical unstable situation favorable to convection processes, where air with low temperature is above air with high temperature. Other research on convective rain events show similar results for other locations [53-56]. 


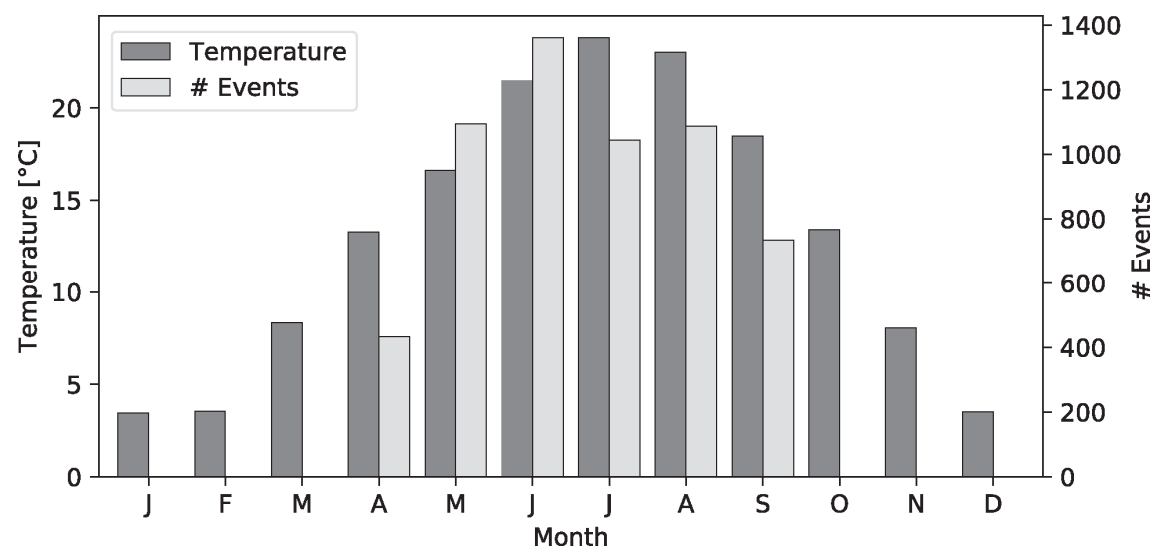

Figure 7. Monthly distributions of average temperature (data provided by ARPA Lombardia) and convective events.

The half-violin plot in Figure 8 confirms the seasonality of convective events but shows that the distribution across years is quite different. It sometimes has a quasi-bimodal shape. The first peak is in late spring/early summer, while the second is at the end of the summer. In other cases, the distribution is unimodal, as in 2014 and 2016, with a high number of convective events lumped in a single period in the middle of summer. The reasons behind these behaviors should be investigated in future research making use of a longer time series.

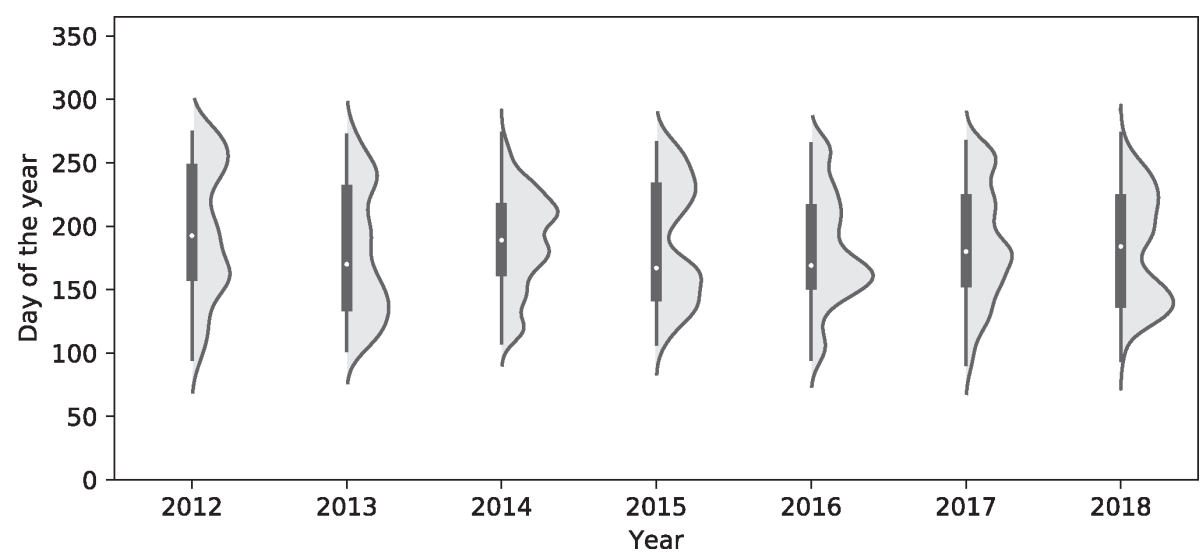

Figure 8. Distribution of the events per day of the year.

The effect of the temperature on the occurrence of convective cells is suggested also at the daily scale, as reported in Figure 9. Most of the convective cells occur in the afternoon, with a peak between 14:00 and 16:00 local time, where the highest number of convective events was recorded (about 400). Given the fact that, in the considered area, the values of daily surface temperature usually reach its maximum from 13:00 to 14:00, the time lag between the peaks of temperatures and the number of convective events could be related to the thermal inertia of the soil surface. Moreover, once the temperature is high enough to allow the breaking of the boundary layer inversion, thermals can reach the lifting condensation level, which represents the limit over which the atmosphere becomes unstable [24]. 


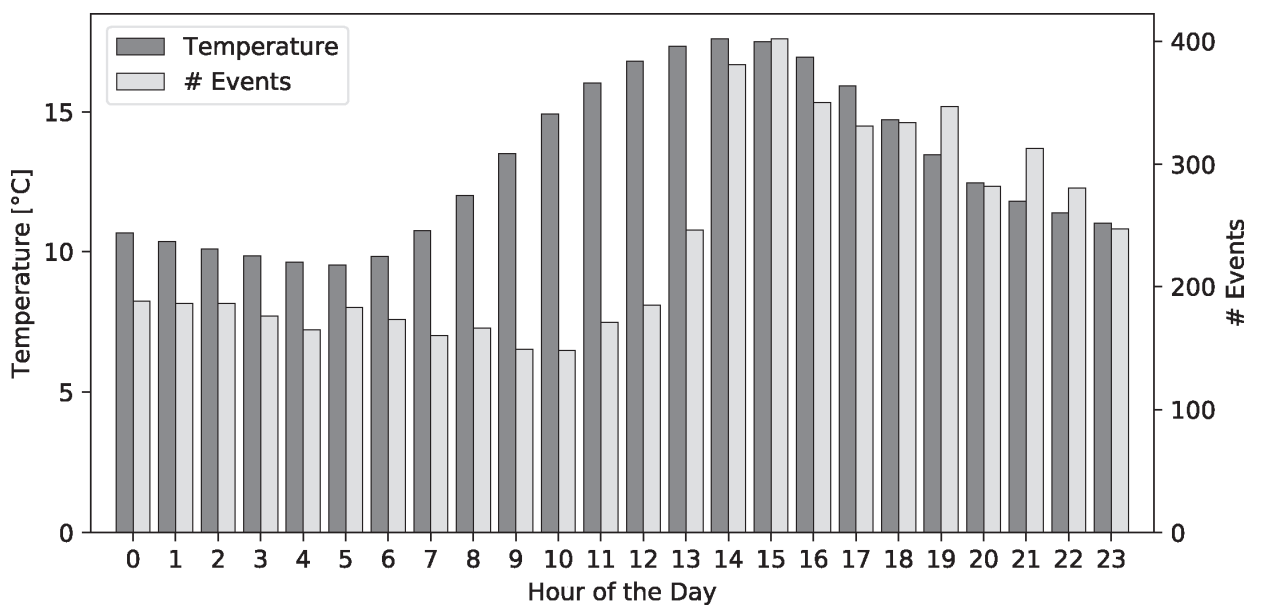

Figure 9. Daytime distribution of temperature (data provided by ARPA Lombardia) and convective events.

Figure 10 shows a data visualization focusing on the monthly distribution of the events crossing the watershed boundary. The convective cells, and the related centers of gravity, have been split into two categories: those belonging to events born outside and heading inside the watershed (IN), and the other ones belonging to events born inside and heading outside the watershed (OUT).

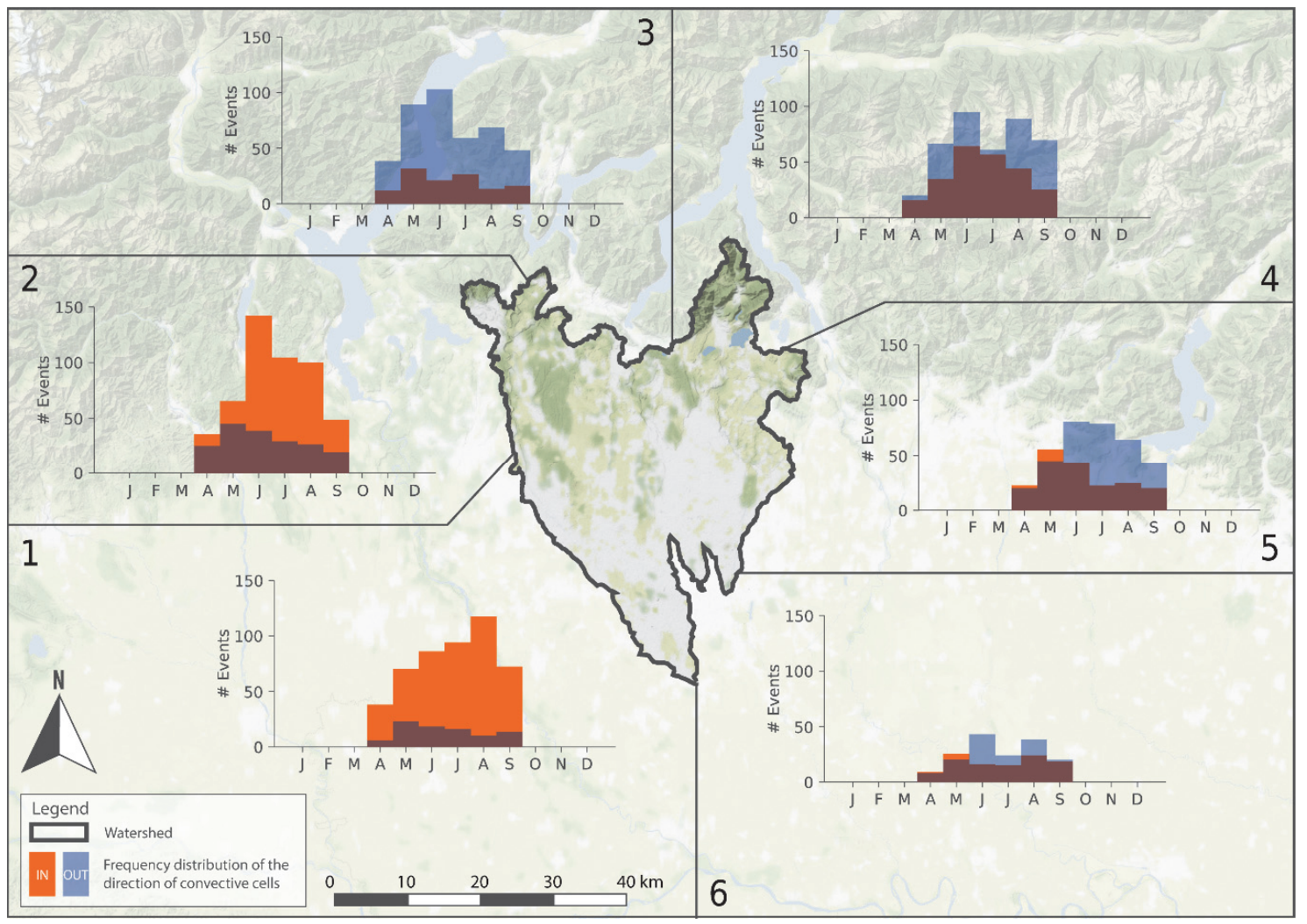

Figure 10. Monthly distribution of the events born inside heading outside (OUT) and born outside heading inside (IN) the basin per month. Orange refers to IN events, blue to OUT ones, while brown bars represent overlapping areas. The watershed border has been split into six different sectors.

This representation is particularly interesting from a meteorological point of view, since it suggests the main directions of the storm trajectories for each month. Most of the cells that enter the basin come from the South-West. It was interesting to notice that the peak number of the IN category in sector 1 
happens in August, while for sector 2 it is in June. This seems to suggest that the circulation patterns that are causing these events are slightly different, probably due to a seasonal related effect. Again, according to the findings in Figure 5, the majority of the events belonging to the OUT category crosses sectors 3, 4, and 5. In particular, for sectors 3, 4, 5, and 6, the OUT peaks happen in June. As a general consideration, the number of events born inside the watershed is slightly less than those coming from outside. In sectors 1 and 2, the number of the IN events is higher than the OUT events; in sector 3 and 4 , the number of the OUT events is always higher than the IN ones; while in sectors 5 and 6, the number of OUT events are larger than IN ones, except for April and May. This is probably due to the location of this sector, with respect to the preferential direction of the convective thunderstorms. It is oriented through the North-West where, additionally, there are the Prealps mountains. When analyzing these mesoscale phenomena, local factors and the interaction between cells themselves plays a key role in the dynamics of cell displacements and triggering.

\subsection{Storm Lifecycle Analysis}

An additional analysis relative to the convective thunderstorm life cycle has been performed. Figure 11 reports the distribution of the events' duration. The duration of the convective events has an exponential distribution. Ninety percent of the events last from 20 minutes to two hours.

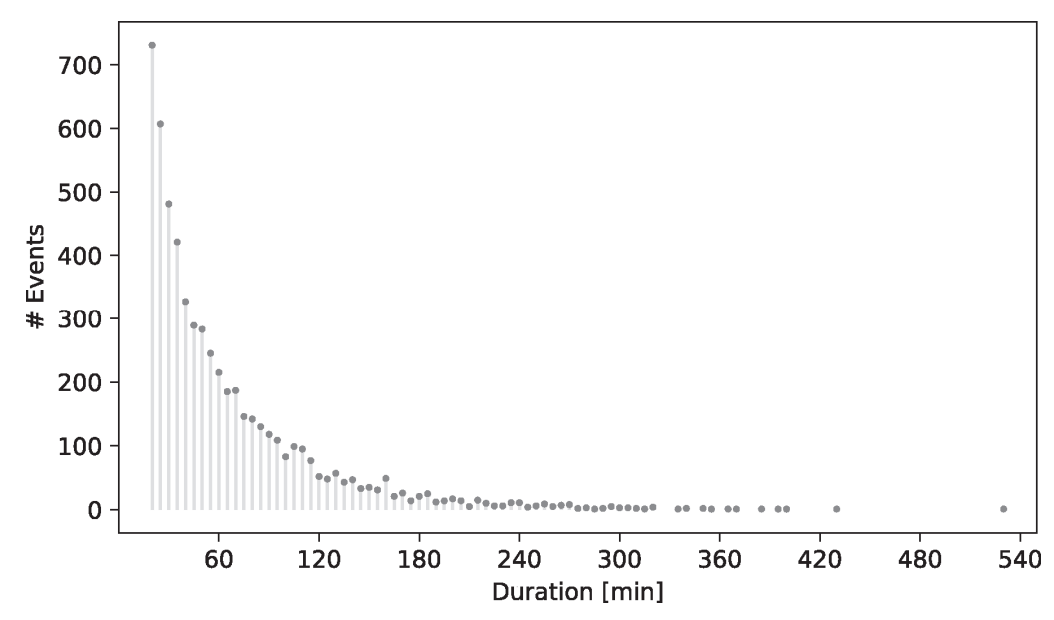

Figure 11. Distribution of the event duration.

Other interesting insights on the convective events lifecycle can be obtained by looking at how the distribution of the spatial statistics of the thunderstorm (mean and maximum reflectivity and area) varies as a function of the event duration. Note that we limit our analysis between 20 and 150 minutes (95\% of the events are within this range) in order to guarantee the statistical significance of the results.

The mean reflectivity (Figure 12, left) has a slightly increasing trend and relatively low variability. This is due to the filtering effect of performing the mean across the spatial dimension.

The trend of the maximum reflectivity (Figure 12, center) is quite different. Half of the data (between the 0.25 and 0.75 quantile) are in the range $46-53 \mathrm{dBZ}$ for short events (20-25 minutes). The range between the 0.25 and 0.75 quantile shifts to higher values if we consider events that last for a longer period. For instance, events lasting for one hour usually assume reflectivity values in the range of 50-56 dBZ. The variability is not affected by the duration.

Conversely, the area interested by convective cells (Figure 12, right) is highly dependent on the duration of the thunderstorm event. Another peculiar feature characterizing this distribution is that it is not symmetric. The median is closer to the 0.25 quantile than to the 0.75 quantile. The latter is a critical feature, because there is a higher probability of having an event characterized by an unusually large areal extension, than one with an unusually small extension. 

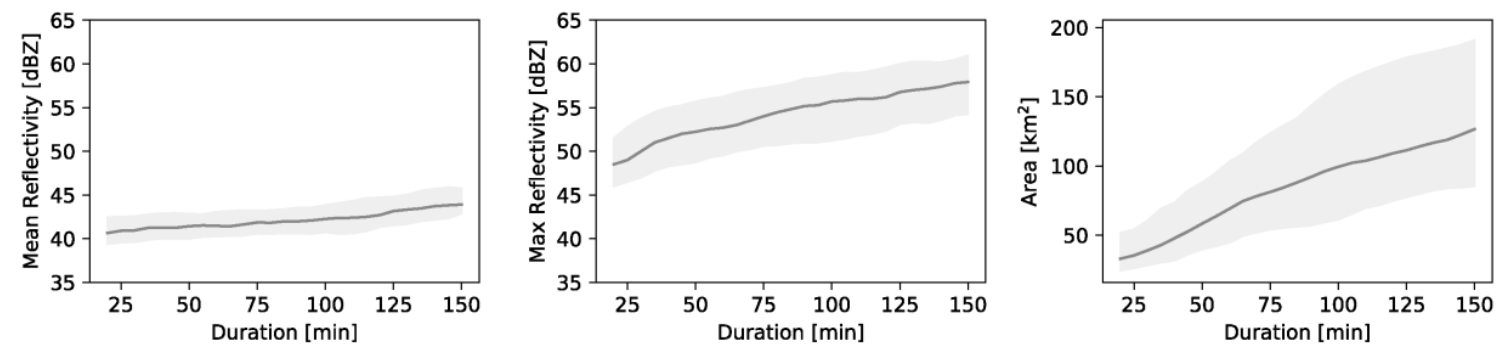

Figure 12. Distribution of mean reflectivity (left), maximum reflectivity (center), and the thunderstorm area (right) as a function of the event duration. The line represents the median of the data. The shaded area covers the interval between 0.25 and 0.75 quantiles.

An increase in the duration of convective events, leads to an increase in the mean and maximum reflectivity and of the area involved in the convection process. The combination of a synchronized growth of the reflectivity, which is strictly related to the rainfall intensity, and of the areal extension of the convective cells, strongly increases the rainfall volume. Consequently, the probability of facing dangerous situations, i.e. intense rainfall over a large area, is much higher in long-lasting storms than in short-lasting ones.

\section{Discussion}

In this paper, we performed a comprehensive analysis of the convective rainfall events that occurred in the seven years from 2012 to 2018 over the Seveso, Olona, and Lambro rivers basin. The convective events composing the considered dataset were detected and tracked by the MeteoSwiss TRT algorithm, which is fed with radar data collected from the Swiss radar network. The huge amount of information sampled had to be visualized in a way that points out the relevant properties of the dataset. We thus decoupled the geospatial and temporal aspects of the convective phenomena, proposing several visual and statistical techniques in order to explore the available data extensively. Further analysis was dedicated to the thunderstorm life cycle.

The visualization of the geospatial distribution allowed us to highlight areas where convective thunderstorms were more frequent. This static distribution highly correlated with the orography of the region: frequencies were higher near the Prealps and lower in the southern area of the basin, characterized by a flat landscape. Additional analysis of the trajectories, followed by the convective cells' centers of gravity, shows that the preferable direction is oriented from South-West to North-East. This is due to the meteorological phenomena characterizing the region. South-West winds carry air masses rich in water vapor originating from the Mediterranean Sea, generating favorable conditions for convection processes. Conversely, the presence of the Alps does not allow a considerable number of events coming from the North to come across the region.

The analyses of the temporal patterns confirm that the occurrence of convective events is strongly correlated to the surface temperature. The latter can thus be considered as one of the main drivers of the atmospheric mechanism generating convective cells. The fact is demonstrated by the distribution of the occurrences in months, and by the intraday average pattern. The events take place only from April to September, with a daily peak after midday in correspondence with the temperature peaks. The annual distributions of the convective events are different year by year, and there is no evidence of an increasing trend in the number of events occurring per year. In this regard, the seven year dataset available is probably too limited to robustly investigate the presence or absence of increasing trends, which could be induced by climate change.

Lastly, we performed an analysis of the main features of the convective cells' life cycle. The duration of the storm life follows an exponential distribution. The events usually last less than 30 minutes, and only a limited number of cells persist on the basin for more than 2 hours. Long-lasting cells usually reach higher values of reflectivity (the average reflectivity is slightly higher, while its 
maximum exhibits a more substantial growth) and cover more extended areas. As a consequence, the impact of long-lasting cells is notably greater than that of short-lasting ones, due to the combined effect of reflectivity (intimately connected with the rainfall intensity) and areal extension of the convective cells on the rainfall volume.

The visual and statistical analyses performed in this paper experimentally confirm well-known characteristics of the convective phenomena and provide new findings regarding the mesoscale and local processes behind these events, showing the high potential of radar-sampled thunderstorm data. Several applications can, therefore, benefit from the results presented. For instance, the convective parameterization scheme of physically based models can be improved, and the feature selection process necessary for machine learning applications can be enhanced. Moreover, potentially dangerous patterns could be identified and exploited by the meteorological units of civil protection agencies to try to mitigate the impacts of these events. Early warning systems could gain some benefits, together with the planning and design of hydraulics infrastructures, and also the deployment of meteorological monitoring sensors. This work could also constitute the starting point to improve the knowledge of severe thunderstorms in the region of study. Considering only severe events, it is possible to identify distinctive factors that concur to their severity. A dataset covering a longer time period would provide the opportunity to evaluate more reliably the effects of climate change on the occurrence, intensity, spatial distribution, and duration of convective rain phenomena.

The framework proposed in this paper can be applied to any area where a time series of snapshots recorded by a radar storm tracking algorithm is available. The statistical analysis and the visualizations obtained can be used as a general-purpose support tool for both nowcasting and climatological studies at the basin scale.

Author Contributions: Conceptualization, Matteo Sangiorgio and Stefano Barindelli; Methodology, Matteo Sangiorgio and Stefano Barindelli; Software, Matteo Sangiorgio and Stefano Barindelli; Writing-Original Draft Preparation, Matteo Sangiorgio and Stefano Barindelli; Writing-Review \& Editing, Matteo Sangiorgio and Stefano Barindelli; Visualization, Matteo Sangiorgio and Stefano Barindelli All authors have read and agreed to the published version of the manuscript.

Funding: This research was partially funded by Fondazione Cariplo (2017 - 0725), project: Lombardy-based Advanced Meteorological Predictions and Observations (LAMPO).

Acknowledgments: We would like to thank MeteoSwiss, in particular Luca Nisi, for providing the TRT algorithm dataset, and Giorgio Guariso for supervising our work and for his useful hints. Thanks also to Enrico Solazzo and Daniele Loiacono for their suggestions regarding the physics of the convective phenomena and their visualization.

Conflicts of Interest: The authors declare no conflict of interest.

\section{References}

1. Goudenhoofdt, E.; Delobbe, L. Statistical Characteristics of Convective Storms in Belgium Derived from Volumetric Weather Radar Observations. J. Appl. Meteorol. Clim. 2013, 52, 918-934. [CrossRef]

2. Fairman, J.G., Jr.; Schultz, D.; Kirshbaum, D.; Gray, S.L.; Barrett, A.I. A radar-based rainfall climatology of Great Britain and Ireland. Weather 2015, 70, 153-158. [CrossRef]

3. Fairman, J.G., Jr.; Schultz, D.; Kirshbaum, D.; Gray, S.L.; Barrett, A.I. Climatology of Size, Shape, and Intensity of Precipitation Features over Great Britain and Ireland. J. Hydrometeorol. 2017, 18, 1595-1615. [CrossRef]

4. Foresti, L.; Sideris, I.V.; Panziera, L.; Nerini, D.; Germann, U. A 10-year radar-based analysis of orographic precipitation growth and decay patterns over the Swiss Alpine region. Q. J. R. Meteorol. Soc. 2018, 144, 2277-2301. [CrossRef]

5. Brooks, H.E.; Doswell, C.A., III; Zhang, X.; Chernokulsky, A.M.A.; Tochimoto, E.; Hanstrum, B.; Nascimento, E.D.L.; Sills, D.M.L.; Antonescu, B.; Barrett, B. A Century of Progress in Severe Convective Storm Research and Forecasting. Meteorol. Monogr. 2018, 59, 18.1-18.41. [CrossRef]

6. Blamey, R.; Middleton, C.; Lennard, C.; Reason, C.J.C. A climatology of potential severe convective environments across South Africa. Clim. Dyn. 2016, 49, 2161-2178. [CrossRef]

7. Levizzani, V.; Cattani, E. Satellite Remote Sensing of Precipitation and the Terrestrial Water Cycle in a Changing Climate. Remote Sens. 2019, 11, 2301. [CrossRef] 
8. Mitchell, J.F.B.; Lowe, J.; Wood, R.A.; Vellinga, M. Extreme events due to human-induced climate change. Philos. Trans. R. Soc. A 2006, 364, 2117-2133. [CrossRef]

9. UNISDR; CRED. The Human Cost of Natural Disasters: A Global Perspective; UNISDR: Geneva, Switzerland, 2015.

10. Wu, Y.; Peng, F.; Peng, Y.; Kong, X.; Liang, H.; Li, Q. Dynamic 3D Simulation of Flood Risk Based on the Integration of Spatio-Temporal GIS and Hydrodynamic Models. ISPRS Int. J. Geo-Inf. 2019, 8, 520. [CrossRef]

11. Wu, C. Comparison and Evolution of Extreme Rainfall-Induced Landslides in Taiwan. ISPRS Int. J. Geo-Inf. 2017, 6, 367. [CrossRef]

12. Li, S.; Cui, Y.; Liu, M.; He, H.; Ravan, S. Integrating Global Open Geo-Information for Major Disaster Assessment: A Case Study of the Myanmar Flood. ISPRS Int. J. Geo-Inf. 2017, 6, 201. [CrossRef]

13. Guimarães, R.F.; Machado, W.P.; De Carvalho, O.; Montgomery, D.R.; Gomes, R.A.T.; Greenberg, H.M.; Cataldi, M.; Mendonça, P.C.; Júnior, O.A.D.C. Determination of Areas Susceptible to Landsliding Using Spatial Patterns of Rainfall from Tropical Rainfall Measuring Mission Data, Rio de Janeiro, Brazil. ISPRS Int. J. Geo-Inf. 2017, 6, 289. [CrossRef]

14. Giustarini, L.; Chini, M.; Hostache, R.; Pappenberger, F.; Matgen, P. Flood Hazard Mapping Combining Hydrodynamic Modeling and Multi Annual Remote Sensing data. Remote Sens. 2015, 7, 14200-14226. [CrossRef]

15. Urban, R.; Štroner, M.; Blistan, P.; Kovanič, L'.; Patera, M.; Jacko, S.; Ďuriška, I.; Kelemen, M.; Szaboa, S. The Suitability of UAS for Mass Movement Monitoring Caused by Torrential Rainfall-A Study on the Talus Cones in the Alpine Terrain in High Tatras, Slovakia. ISPRS Int. J. Geo-Inf. 2019, 8, 317. [CrossRef]

16. Doswell, C.A., III; Brooks, H.E.; Maddox, R.A. Flash flood forecasting: An ingredients-based methodology. Weather Forecast. 1996, 11, 560-581. [CrossRef]

17. Doswell, C.A. Severe convective storms-An overview. In Severe Convective Storms; American Meteorological Society: Boston, MA, USA, 2001; pp. 1-26.

18. Peleg, N.; Skinner, C.; Fatichi, S.; Molnar, P. Temperature effects on the spatial structure of heavy rainfall modify catchment hydro-morphological response. Earth Surf. Dyn. 2020, 8, 17-36. [CrossRef]

19. Wasko, C.; Sharma, A.; Westra, S. Reduced spatial extent of extreme storms at higher temperatures. Geophys. Res. Lett. 2016, 43, 4026-4032. [CrossRef]

20. Wasko, C.; Sharma, A. Global assessment of flood and storm extremes with increased temperatures. Sci. Rep. 2017, 7, 7945. [CrossRef]

21. Prein, A.; Liu, C.; Ikeda, K.; Trier, S.B.; Rasmussen, R.M.; Holland, G.J.; Clark, M. Increased rainfall volume from future convective storms in the US. Nat. Clim. Chang. 2017, 7, 880-884. [CrossRef]

22. Peleg, N.; Shamir, E.; Georgakakos, K.P.; Morin, E. A framework for assessing hydrological regime sensitivity to climate change in a convective rainfall environment: A case study of two medium-sized eastern Mediterranean catchments, Israel. Hydrol. Earth Syst. Sci. 2015, 19, 567-581. [CrossRef]

23. Fadhel, S.; Rico-Ramirez, M.A.; Han, D. Sensitivity of peak flow to the change of rainfall temporal pattern due to warmer climate. J. Hydrol. 2018, 560, 546-559. [CrossRef]

24. Peleg, N.; Marra, F.; Fatichi, S.; Molnar, P.; Morin, E.; Sharma, A.; Burlando, P. Intensification of Convective Rain Cells at Warmer Temperatures Observed from High-Resolution Weather Radar Data. J. Hydrometeorol. 2018, 19, 715-726. [CrossRef]

25. Davini, P.; Bechini, R.; Cremonini, R.; Cassardo, C. Radar-Based Analysis of Convective Storms over Northwestern Italy. Atmosphere 2011, 3, 33-58. [CrossRef]

26. Llasat, M.C.; Marcos, R.; Turco, M.; Gilabert, J.; Llasat-Botija, M. Trends in flash flood events versus convective precipitation in the Mediterranean region: The case of Catalonia. J. Hydrol. 2016, 541, 24-37. [CrossRef]

27. Anagnostou, E.N.; Anagnostou, M.N.; Krajewski, W.; Kruger, A.; Miriovsky, B.J. High-Resolution Rainfall Estimation from X-Band Polarimetric Radar Measurements. J. Hydrometeorol. 2004, 5, 110-128. [CrossRef]

28. Lagasio, M.; Parodi, A.; Pulvirenti, L.; Meroni, A.N.; Boni, G.; Pierdicca, N.; Marzano, F.S.; Luini, L.; Venuti, G.; Realini, E.; et al. A Synergistic Use of a High-Resolution Numerical Weather Prediction Model and High-Resolution Earth Observation Products to Improve Precipitation Forecast. Remote Sens. 2019, 11, 2387. [CrossRef]

29. Ricciardelli, E.; Di Paola, F.; Gentile, S.; Cersosimo, A.; Cimini, D.; Gallucci, D.; Geraldi, E.; La Rosa, S.; Nilo, S.T.; Ripepi, E.; et al. Analysis of Livorno Heavy Rainfall Event: Examples of Satellite-Based Observation Techniques in Support of Numerical Weather Prediction. Remote Sens. 2018, 10, 1549. [CrossRef] 
30. Sangiorgio, M.; Barindelli, S.; Biondi, R.; Solazzo, E.; Realini, E.; Venuti, G.; Guariso, G. Improved extreme rainfall events forecasting using neural networks and water vapor measures. In Proceedings of the 6th International Conference on Time Series and Forecasting (ITISE), Granada, Spain, 25-27 September 2019; Volume 2, pp. 820-826.

31. Sangiorgio, M.; Barindelli, S.; Biondi, R.; Solazzo, E.; Realini, E.; Venuti, G.; Guariso, G. A Comparative Study on Machine Learning Techniques for Intense Convective Rainfall Events Forecasting. In Advances in Time Series and Forecasting; Springer: Cham, Switzerland, 2020; stage of publication (accepted).

32. Hamann, U.; Zeder, J.; Beusch, L.; Clementi, L.; Foresti, L.; Hering, A.; Nerini, D.; Nisi, L.; Sassi, M.; Germann, U. Nowcasting of Thunderstorm Severity with Machine Learning in the Alpine Region. 2019. Available online: https://repositorio.aemet.es/handle/20.500.11765/10617 (accessed on 22 March 2020).

33. Mecikalski, J.R.; Bedka, K.M. Forecasting Convective Initiation by Monitoring the Evolution of Moving Cumulus in Daytime GOES Imagery. Mon. Weather Rev. 2006, 134, 49-78. [CrossRef]

34. Medina, B.; Carey, L.; Amiot, C.G.; Mecikalski, R.; Roeder, W.P.; McNamara, T.M.; Blakeslee, R.J. A Random Forest Method to Forecast Downbursts Based on Dual-Polarization Radar Signatures. Remote Sens. 2019, 11, 826. [CrossRef]

35. Hering, A.M.; Morel, C.; Galli, G.; Sénési, S.; Ambrosetti, P.; Boscacci, M. Nowcasting thunderstorms in the Alpine Region using a radar based adaptive thresholding scheme. In Proceedings of the Third European Conference on Radar Meteorology 2004, Visby, Sweden, 6-10 September 2004.

36. Hering, A.M.; Sénési, S.; Ambrosetti, P.; Bernard-Bouissières, I. Nowcasting thunderstorms in complex cases using radar data. In Proceedings of the WMO Symposium on Nowcasting and Very Short Range Forecasting, Toulouse, France, 5-9 September 2005.

37. Quinan, P.S.; Meyer, M. Visually Comparing Weather Features in Forecasts. IEEE Trans. Vis. Comput. Graph. 2015, 22, 389-398. [CrossRef]

38. Nisi, L.; Hering, A.; Germann, U.; Romppainen-Martius, O. A 15-year hail streak climatology for the Alpine region. Q. J. R. Meteorol. Soc. 2018, 144, 1429-1449. [CrossRef]

39. Haberlie, A.; Ashley, W. A Radar-Based Climatology of Mesoscale Convective Systems in the United States. J. Clim. 2019, 32, 1591-1606. [CrossRef]

40. Karklinsky, M.; Morin, E. Spatial characteristics of radar-derived convective rain cells over southern Israel. Meteorol. Z. 2006, 15, 513-520. [CrossRef]

41. Köppen, W.P. Die Klimate der Erde: Grundriss der Klimakunde. Geogr. J. 1925, 65, 74.

42. Germann, U.; Galli, G.; Boscacci, M.; Bolliger, M. Radar precipitation measurement in a mountainous region. Q. J. R. Meteorol. Soc. 2006, 132, 1669-1692. [CrossRef]

43. Germann, U.; Joss, J. Mesobeta Profiles to Extrapolate Radar Precipitation Measurements above the Alps to the Ground Level. J. Appl. Meteorol. 2002, 41, 542-557. [CrossRef]

44. Hunter, J.D. Matplotlib: A 2D Graphics Environment. Comput. Sci. Eng. 2007, 9, 90-95. [CrossRef]

45. Seaborn: Statistical Data Visualization. Available online: https://seaborn.pydata.org/ (accessed on 21 January 2020).

46. McKinney, W. Data structures for statistical computing in python. In Proceedings of the 9th Python in Science Conference, Austin, TX, USA, 28 June-3 July 2010; pp. 51-56.

47. Geoplot. Available online: https://residentmario.github.io/geoplot (accessed on 21 January 2020).

48. Cartopy Project Web Page. Available online: https://scitools.org.uk/cartopy (accessed on 21 January 2020).

49. GDAL/OGR Geospatial Data Abstraction software Library. Open Source Geospatial Foundation. 2020. Available online: https://gdal.org (accessed on 21 January 2020).

50. Toblerity/Shapely. Available online: https:/github.com/Toblerity/Shapely (accessed on 21 January 2020).

51. QGIS. QGIS Project. 2020. Available online: http://www.qgis.org/ (accessed on 21 January 2020).

52. Panziera, L.; Gabella, M.; Germann, U.; Martius, O. A 12-year radar-based climatology of daily and sub-daily extreme precipitation over the Swiss Alps. Int. J. Clim. 2018, 38, 3749-3769. [CrossRef]

53. Burcea, S.; Cică, R.; Bojariu, R. Radar-derived convective storms' climatology for the Prut River basin: 2003-2017. Nat. Hazards Earth Syst. Sci. 2019, 19, 1305-1318. [CrossRef]

54. Liu, W.; Li, X. Life Cycle Characteristics of Warm-Season Severe Thunderstorms in Central United States from 2010 to 2014. Climate 2016, 4, 45. [CrossRef] 
55. Galanaki, E.; Lagouvardos, K.; Kotroni, V.; Flaounas, E.; Argiriou, A. Thunderstorm climatology in the Mediterranean using cloud-to-ground lightning observations. Atmos. Res. 2018, 207, 136-144. [CrossRef]

56. Fridlind, A.M.; Van Lier-Walqui, M.; Collis, S.; Giangrande, S.E.; Jackson, R.C.; Li, X.; Matsui, T.; Orville, R.; Picel, M.H.; Rosenfeld, D.; et al. Use of polarimetric radar measurements to constrain simulated convective cell evolution: A pilot study with Lagrangian tracking. Atmos. Meas. Tech. 2019, 12, 2979-3000. [CrossRef]

(C) 2020 by the authors. Licensee MDPI, Basel, Switzerland. This article is an open access article distributed under the terms and conditions of the Creative Commons Attribution (CC BY) license (http://creativecommons.org/licenses/by/4.0/). 